\title{
The Rehabilitation of the Widows in Pattani Province, Thailand
}

\author{
Kanlaya Daraha (Corresponding author) \\ Dept. of Social Sciences, Princes of Songkla University \\ A.Muang CH.Pattani, Thailand \\ Tel: 0066-873927324Ｅ-mail: dkallaya2500@gmail.com
}

Received: April 29, 2013 Accepted: June 11, 2013 Published: July 21, 2013

doi:10.5296/ijssr.v1i1.3598 URL: http://dx.doi.org/10.5296/ijssr.v1i1.3598

\begin{abstract}
The purpose of the research aimed to 1) Investigate the rehabilitation of the widows affected by the violence in the Province Pattani, Thailand. 2) Provide the guideline for the government and institutions to find ways to rehabilitate the widows affected the violence in the Province Pattani, Thailand.

The findings of the research were summarized: There are increasing the widows drastically because of the violence crisis for a long time since 2004. The government has the policy to rehabilitate the widows affected by the violence. Ministry of Human Security and Social Development helps the budget per month for the widows. In the Deep South has the Center for rehabilitation the populations and the widows affected by the violence i.e. South Coordination Center, that coordinate with Prince of Songkla University, Pattani Campus and the office of Human Security and Social Development in the Province Pattani and specifically it has the group of the widows "We Peace" for empowerment the widows and the Center of the Health care. Some opinions suggest the activities to collaborate with the widows, the training career for the widows and it must have the community for watching the strangers every village and the government should construct the conciliation in the Deep South of Thailand for conducting "the Social Well- Being".
\end{abstract}

Keywords: Widows, the Rehabilitation, Province Pattani

\section{Introduction}

In the past nine years, the violence situation has spiked in the Deep South (Pattani, Yala, Narathiwat Provinces) and parts of Songkla Province (Nathawi, Sabayoi. Chana and Thepa 
districts). Since January, 2004, the violence situation is occurred in these provinces, more than 3,000 people have died and more than 5,000 have been injured. More than 7,000 children in the area have been orphaned by the conflict. It is higher than tsunami orphans, Watanayagornkorn Panitan said and Jitpiromsri Srisompob views that November is always the month that violent peak (Jagan, 2008).

The government has the policy for rehabilitating the people affected the violence situation and in 2012, the government supports the Southern Border Province Administrative Center for rehabilitating them 2,080 baht (Prime Minister Secretariat, 2012).

Ministry Social Development and Human Security found that the ongoing violence in the last eight years, since January 2004 - March 2012. The widows are affected by the violence situation 2,450 people. There were classified as Narathiwat 787, Yala 689 and Pattani 898 and Songkla 76 (The Mental Health Center, District 15). In the Deep South, the loan mother faced the economic hardship psychological and mental health and the quality of life get worst and some of them never have worked. (Deep South Watch, 2009).

Pattani is one of the four provinces of Thailand where the majority of the population are Malay Muslim, making up $88 \%$ of the population. They speak the Pattani Malay language, although many can also speak Thai. The Pattani Malays are very similar in ethnicity and culture to the Malays of Kelantan, Malaysia.

\subsection{We Peace}

Mrs. Jamjuree Soraya, the training for Peace and chairman of the working group from Prince of Songkla University. She views that the rehabilitation is the Peace for reducing the violence in the future and Mrs. Pokkeetaedaoh Pateemah, the Director of woman for Peace or "We Peace". She is also expressed the confidence in the power of rehabilitation. The Rehabilitation Work, for people affected by the violence situation. It must have the power to rise up and fight the problem with themselves. That is the capacity to achieve people in the region and the Civil society is the part of resolving that is occurred. The Echoes of family loss and thus Civil Society groups are encouraged and empower to talk the people affected by the violence situation and can make them stand with themselves.

\subsection{The Deep South Coordination Center}

The Deep South Coordination Center has the big role for rehabilitating the people affected the violence in the Deep South. In 2006, the Deep South Watch Coordination Center discovered since the violence starting in 2004, there had been some 310 widows affected by the violence. Because of the psychological and mental illness and economic hardship these women are faced. The center empowers and encourages them and learns to help them sustainable.(South Coordination Center, 2012 ) and the Center has also been working with children who affected by the violence, specifically in Pattani province and in 2008, it provides rehabilitation for children and collaborative with the Mental Health and assist 72 children and Dr. Guning Metta, the Deep South Coordination Center views that:

In the past, the Deep South Coordination Center was a recipient of other people's assistance, 
but now it wishes to focus on helping others."

\subsection{Center Health Care}

The hospital is the big role for assisting and rehabilitating people affected the violence and Dr. Hasuwannakit Supat, the Director of Chana Hoapital Songkla Province indicated that:

Over the next five years, we need to create high quality rehabilitation services for those people impacted by the violence"

Hospitals have admitted a high number of patients from the Deep South of Thailand or due to the increase in violence over the past five years. Unfortunately, the hospital workers are faced with addressing the needs of numerous patients, resulting in a reduction in the quality of care hospital patients. Though it is critical that patients receive better care so that they have new opportunities in life, the proper care and treatment required for this to happen is seldom provided.

As the present, the hospitals must have the priority treating a large number of patients. While many patients may receive financial compensation for their injuries, very little moral support is provided because of this stress on treating a high number of patients.

Over the next five years, it is necessary to improve the quality of treatment for patients, and this should be provided under the supervision of the government. Financial support may be support by the various sectors and government agencies that are involved with improving treatment. Meanwhile, more local psychologists should be employed to offer assistance and support to those undergoing emotional trauma (South Coordination Center, 2012).

\section{Analysis of Assistance Provided after Violence}

Dr. Tohmeena Petdao, the Director of Mental Health Center, District 15, Department of Mental Health, Public Health Ministry mentioned that the victim from the Deep South of Thailand can contact the government offices simultaneously and they can receive the good relationship and good convenience and get compensation. It calls "One Stop Service" but the government does not so call it and the victim should assist from NGOs in region.

Deputy Public Health Vicharn said that from January 2004 to May 2008, there were 8,009 violent incidents in the Deep South. The incidents affected the 1,404 women becoming widows and 2,561 children becoming orphans. The affected women and orphans have suffered traumatic stress and need rehabilitation on a long -term basis.,

Mr. Vicharn said that the Ministry of Public Health had set up mental health rehabilitation centers at general and community hospitals four districts in Songkla. Each center had one or three psychologists and focuses on three target groups. The first group consists of the general public. The second group consists of government officials who are classified as a risk group. The third group consist of the orphans and relatives of those who died from the unrest. This group consists of 10,000 persons and the were affected directly by violent situation (Foreign Office, the Government Public Relations Department, Office of the Prime Minister, 2008). 
Mechanisms and procedures to rehabililitate the mind (Department of Health)
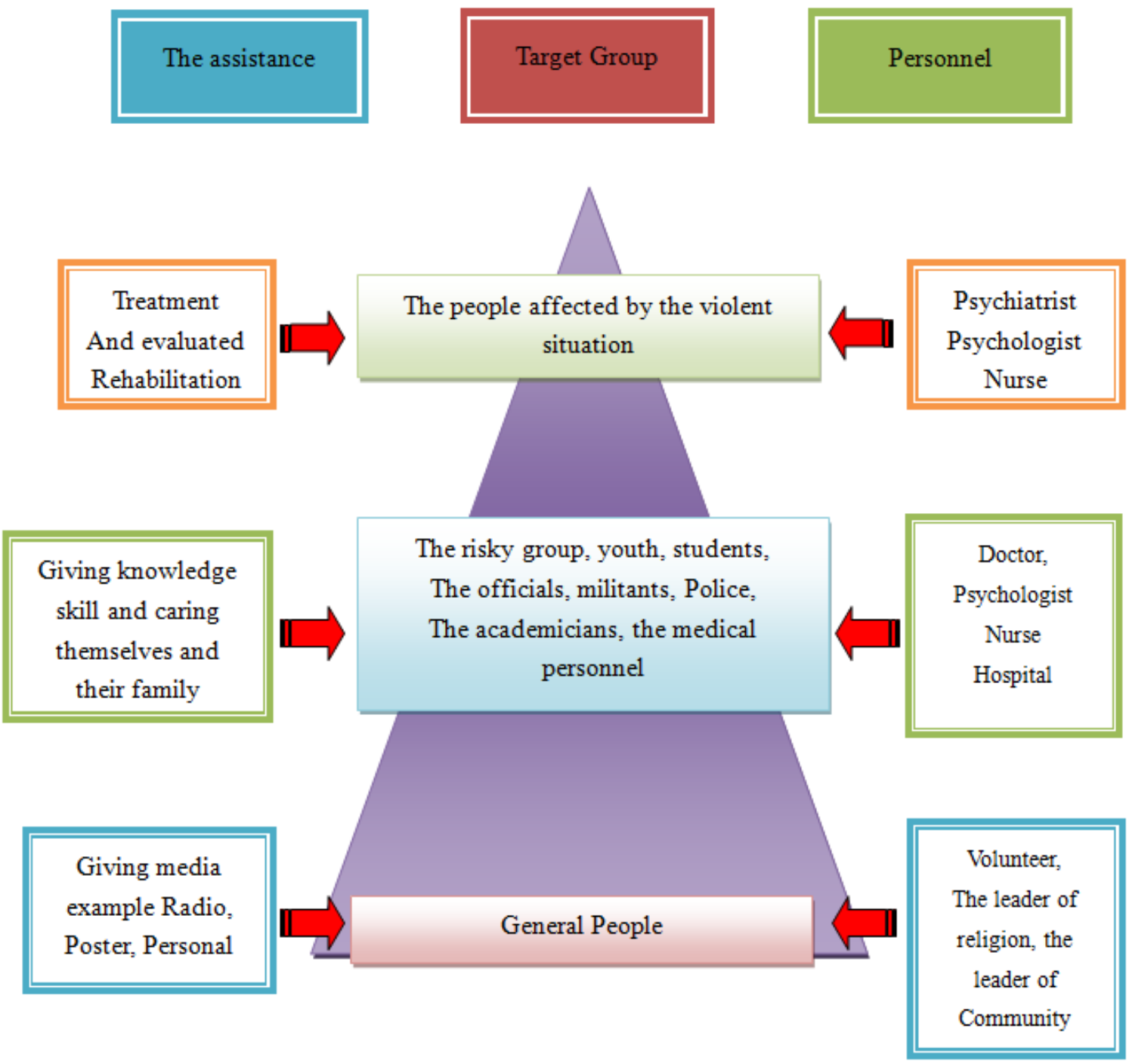

Figure 1. The Rehabilitation from Mental Health Center, District 15, Department of Mental Health, Public Health Ministry in the Deep South

There are 16 widows communities in Pattani and in 2012, there are two communities to be the head for rehabilitating the widows affected the violence situation in Pattani (The Mental Health Center, District 15). 


\section{Method of Rehabilitation}

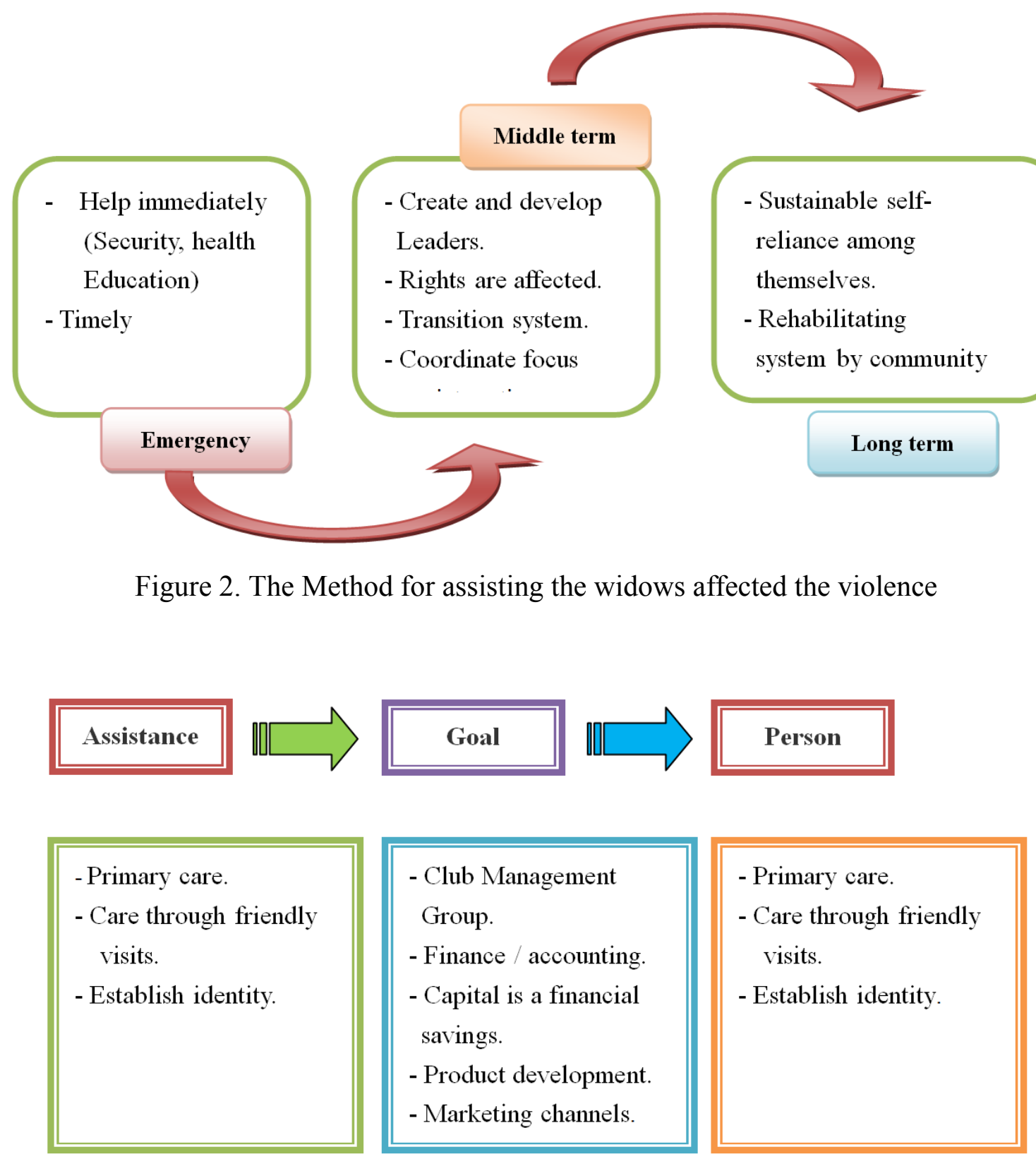

Figure 3. The strengthening of three goals for communities /networks

\subsection{Step of the Important Work}

1) Integrating with the government, private sector and the academicians in universities and other organizations.

2) Starting with the activities, gives the budget for doing the jobs and the scholarships.

3) Developing the key women or the model of the widows.

4) Constructing the system, rehabilitate and therapy. 
5) Collaborative with the religion organization, provincial and local organization.

\section{Methodology}

The research is done through qualitative approach to collect through extensive interviews, casual conversation, formal and informal observations and analyzes the research data. In-depth portraits of a small number of individual widows with seven Buddhists and twenty-three Muslims in Amphoe Muang Pattani province, Thailand would however provide and support much fuller access to their views across a range of the issues of problem. A total of interviews semi- structure interviews with open-ended questions were conducted for the purpose of study.. All interviewers were audio tape -recorded and informal conservations. In this study, the data were gathered to learn of each case. After that, the data obtained from this case was analyzed.

\section{Result}

The Buddhists, they need the army guard in the Deep South and the government should get the scholarship to the children until finish Bachelor Degree and construct their career sustainable and they propose the government and the stake holders, the organizations take care the orphans and the widows and construct the reconciliation in the Deep South.

The Muslims, They trust the private sectors more than the government officials. They need the surveillance in their community and prohibit the strangers to enter. They must have the widows' network or widowhood for assisting together. They propose the government to assist their orphans for studying and working. They need the communities take care themselves and every organization should coordinate and collaborate for conduct wellbeing of the orphans. The government should construct the reconciliation and the harmony in the Deep South.

\section{Recommendation}

- The government must stop the violence situation and construct the reconciliation sustainable.

- It should have the scholarship for students, specifically Muslim Youth.

- The community must construct the surveillance in their community.

- It must have Health Care for the widows and the orphans.

- The role of family and family members must be strengthened because they must empower the widows to stand with themselves and take care the orphans.

- It should construct the activities for rehabilitate the widows.

- It should have Home visit and empower the widows and the orphans frequently.

- It must respect the Human Rights for every target groups.

- It should have media Language for people. 


\section{References}

Deep South Watch. (2009). Feelings from "the virtual world" - people's hearts have separated already. Retrieved October 29, 2012, from http://www.deepsouthwatch.org/node/284

Department of Mental Health Center, District 15. (2012). Executive Summary 8 years of Administrative Rehabilitation have been the psychological impact on the violent Situation in the Deep South. Ministry of Public Health.

Foreign Office, the Government Public Relations Department. (2008). Mental Rehabilitation for children affected by Unrest in the South. Office the Prime Minister.

Jagan Larry. (2008). Violence worsens in Thailand. Retrieved June 25, 2012 from http://www.thenational.ae/newa/world/asia-pacific/violemce-worsens-inthailand

Mental Rehabilitation for children affected by Unrest in the South. (n.d.). Retrieved May 30, 2013, from http://thailand.prd.go.th/views_news.php?id=3595\&a=2

Prime Minister Secretariat. (2012). Government House. The petition for healing the affected.

Prime Minister Secretariat. (2012). Government House. His approval. Rules and procedures to help heal and restore the damage has been affected by the unrest in the southern Provinces. And approve the budget for fiscal year.

South Coordination Center. (2011). Report Summary of Activities for learning and the exchange of women. The center of the events of the outbreak and the Community.

South Coordination Center. (2012). Remedy Help Center Pattani. Procedures for obtaining remedies to help those affected. Unrest in the province of Pattani.

The Rehabilitation of Civil Society in the Deep South. (n.d.). Retrieved October 29, 2012, from http://prachatai.com/journal/2012/01/38599

Violence worsens in Thailand. (n.d.) Retreived October 30 October, 2012, from http://thenational.ae/news/world/asia-pacific/violence-worsens-in-thailand

\section{Copyright Disclaimer}

Copyright reserved by the author(s).

This article is an open-access article distributed under the terms and conditions of the Creative Commons Attribution license (http://creativecommons.org/licenses/by/3.0/). 